\title{
OPTIMIZED DETERMINATION OF 3D COORDINATES IN THE SURVEY OF INACCESSIBLE POINTS OF BUILDINGS - EXAMPLE OF APPLICATION IMPLEMENTED IN FREE SOFTWARE \\ Determinação otimizada de coordenadas 3D no levantamento de pontos inacessíveis de edificações - exemplo de aplicação implementado em software livre
}

Leandro Luiz Silva de França ${ }^{1}$ - ORCID: 0000-0003-0863-1926

Andréa de Seixas ${ }^{1}$ - ORCID: 0000-0002-5879-4902

Luciene Ferreira Gama² - ORCID: 0000-0002-2373-7772

João Naves de Moraes $^{1}$ - ORCID: 0000-0002-8350-4946

${ }^{1}$ Universidade Federal de Pernambuco, Departamento de Engenharia Cartográfica, Programa de Pós-Graduação em Ciências Geodésicas e Tecnologias da Geoinformação, Recife, Pernambuco, Brasil

${ }^{2}$ Instituto Federal de Educação, Ciência e Tecnologia da Paraíba - IFPB, Curso Superior de Tecnologia em Geoprocessamento, João Pessoa, Paraíba, Brasil

E-mail: geoleandro.franca@gmail.com; adeseixas7@gmail.com; gamalf@gmail.com; joaosevan@gmail.com

Received in $7^{\text {th }}$ September 2020

Accepted in $12^{\text {th }}$ March 2021

\section{Abstract:}

The forward intersection method is already widely used in the geodetic survey of coordinates of inaccessible points, especially when only angle measurements are available, in this case, also called the triangulation method. However, the mathematical solution of the 3D forward intersection with the analytical definition of spatial lines, resolved by the Minimum Distances Method, is still not widespread in the academic and professional environment. This mathematical modeling determines the 3D coordinates of a point located in the middle of the minimum distance between two or more spatial lines, which spatially "intersect" towards the observation point. This solution is more accurate than others presented in the literature because it simultaneously solves the problem of $3 D$ determination of a point by the method of least squares, in addition to providing an estimate of the coordinate precision, which are inherent to the adjustment. This work, therefore, has the objective of explaining the Minimum Distances Method for the spatial intersection of targeted measurements with a Total Station from two or more known observation points for the 3D determination of inaccessible points located in corners of buildings. For the analysis of the method, a Python tool was developed for QGIS that calculates the 3D coordinates and generates the adjustment processing report, being applied with real observations of the Geodetic survey of the SUDENE building, in Recife-PE. The methodology developed in this work How to cite this article: FRANCA, L.; DE SEIXAS, A.; GAMA, L.; MORAES, J. Optimized determination of 3D coordinates in the survey of inaccessible points of buildings - example of application implemented in free software. Bulletin of Geodetic Sciences. 27(2): e2021017, 2021. 
proved to be suitable for measurements of large structures, achieving spherical precision better than $\pm 1.0 \mathrm{~cm}$, following the Brazilian standards for urban cadastre.

Keywords: Forward Intersection Method, Minimum Distances, Method of least squares, 3D Coordinates, Python, QGIS

\section{Resumo:}

O método da interseção à vante já é bastante empregado no levantamento geodésico de coordenadas de pontos inacessíveis, principalmente, quando se dispõe apenas de medições de ângulos, neste caso, também denominado método da triangulação. Entretanto, a solução matemática da interseção à vante 3D com a definição analítica de retas espaciais, resolvida pelo Método das Distâncias Mínimas, ainda é pouco difundido no ambiente acadêmico e profissional. Esta modelagem matemática determina as coordenadas 3D de um ponto localizado no meio da distância mínima entre duas ou mais retas espaciais, que se "interceptam" espacialmente em direção ao ponto de observação. Esta solução é mais acurada que outras apresentadas na literatura por resolver simultaneamente o problema da determinação 3D de um ponto pelo Método dos Mínimos Quadrados (MMQ), além de fornecer as precisões das coordenadas, as quais são inerentes ao processo de ajustamento. Este trabalho, portanto, tem o objetivo de explanar o Método das Distâncias Mínimas para a interseção espacial de visadas medidas com estação total a partir de dois ou mais pontos de observação conhecidos para a determinação 3D de pontos inacessíveis situados em quinas de edificações. Para a análise do método foi desenvolvida uma ferramenta em Python para o QGIS que calcula as coordenadas 3D e gera o relatório de processamento do ajustamento, sendo aplicada com observações reais do levantamento geodésico do prédio da SUDENE, em Recife-PE. A metodologia desenvolvida neste trabalho se mostrou adequada para medições de grandes estruturas, alcançando precisões esféricas melhores que $\pm 1,0 \mathrm{~cm}$ e atendendo as normas nacionais para cadastro urbano.

Palavras-chave: Método da Interseção à Vante, Distâncias Mínimas, MMQ, Coordenadas 3D, Python, QGIS

\section{Introduction}

The monitoring of engineering structures has the objective of verifying their variations over time, evaluating the stability of the constructions and the resulting risks ( Alves et al., 2012; De Seixas et al., 2007). For this, there is a need for continuous monitoring and control of the shape and surface of objects (De Seixas et al., 2014; Mao et al., 2013; De Seixas, 2004) with techniques of adequate accuracy for this purpose.

With the advent of Building Information Modeling (BIM), geodetic surveying has become an essential factor in quality control from the beginning to the end of a work (França, 2018), due to the need to check whether the planned (as-planned) files BIM corresponds to the constructed reality (as-build) and if the reality faithfully reflects this set of data, avoiding both loss and excess of BIM elements (Ariza-López et al., 2019), guaranteeing economic benefits in the management of the construction phases ( Mill et al., 2013). 
Although the use of terrestrial laser scanners is being widely used for high precision surveying, its technology is based on the principle of measuring distances, where the range is correlated to accuracy (Haddad, 2011), and the accuracy of the points is restricted to short distances (1-150m) (Fawzy, 2019), in addition to depending on the material surfaces and target reflectivity (Mill et al., 2013).

In cases where distance measurements cannot be found due to the limitation of the measuring instrument or access to the point, the coordinates can also be calculated, using theodolites or total stations only with observations horizontal and vertical angles, positioned at two or more stations of known coordinates (De Seixas, 2009; Martins, 2013).

Among the geodetic survey techniques for determining 3D coordinates without the need for distance measurements, the Forward Intersection Method can be cited, where the point coordinates can be calculated using both trigonometric and analytical mathematical models, involving planimetry $(X, Y)$ initially and then altimetry $(Z)$ or involving planialtimetry $(X, Y, Z)$ at the same time (Kahmen, 2006).

This work focuses on the 3D determination of the optical intersection of spatial lines (Nadal, 2000), using the Minimum Distances Method, being the most suitable due to its mathematical modeling and precision of the results (Martins \& Silva, 2017).

The design of this method was initially intended for the industry to determine 3D coordinates in Industrial Measurement Systems based on Theodolites or Videoteodolites (Staiger, 1988; Roic, 1996), making it possible to scan objects in dangerous, inaccessible or impossible to be locations signaled (Roic, 1996).

It is noteworthy that, mainly due to the inherent random errors of the observations, in addition to the variables of the physical model related to the influence the refraction and curvature of the Earth (Gomes et al., 2007), depending on the area and the accuracy required by the survey, it is practically impossible for two lines of view from different stations to be exactly concurrent in the same geometric point, even passing very close to him (Fawzy, 2019; Mao et al., 2013; Martins, 2013).

Thus, in order for the values of the point coordinates to be correctly estimated, the observations can be adjusted, so that the sum of the distances from the point to the lines that support the sight lines is minimal in relation to the adjusted point (Martins \& Silva, 2017; Martins, 2013; Silva \& Segantine, 2015; Jung et al., 2016).

At the 3D optical intersection by the Minimum Distances Method, at least two stations in different positions of known coordinates must be used to satisfy their mathematical modeling (Martins, 2013). The quality of the results will depend, mainly, on the precision of the coordinates, where the stations will be occupied, the precision of the measuring instrument and the geometry of the spatial intersection (Cheng et al., 2020).

The best geometric configuration, for example, in planimetry, for the definition of a point from the intersection of lines is that in which the intersection occurs from lines perpendicular to each other. Möser \& Müller (2000) introduce the flat plummet method for ensuring the verticality of structures. The configuration of the vertices to be occupied by total stations is presented for the procedure of lifting and locating predominantly vertical structures, highlighting the intersection of vertical planes perpendicular to each other, whose intersections represent the corners of the building's faces (Okiemute et al., 2018; Palazzo et al., 2006). 
The objective of this work is, therefore, to explain the Forward Intersection Method with mathematical solution through the Minimum Distances, applying it in a case with real survey data in the field to determine the coordinates of inaccessible points (located at the top of a building) with algorithms implemented in free software.

The computational tool developed for this work allows the adjustment of observations based on measurements carried out at two or more reference stations, enabling the increase of quality in the simultaneous determination of the 3D coordinates of the spatial intersection of lines. Thus, optimizing the method, for situations that involve more than two lines of sight, enabling better geometric configurations when necessary.

All theory and resources provided by this work can serve as a subsidy for the evaluation of the three-dimensional positional quality of geodetic surveys of buildings for the urban land register (cadastre), regulated by Decree-Law No. 9,310 (Brasil, 2018).

\section{3D Optical Intersection by The Minimum Distance Method}

The first record of this method is presented by Staiger (1988) in his doctoral thesis at TU-Munich as a highly accurate 3D optical measurement technique for the industry, being verified by Allan (1996) as an efficient method for short distances.

Moreira (1998) used the method to verify subsidence or structural displacements in load tests in engineering works. Nadal (2000), in turn, studied the 3D optical intersection in engineering experiments to measure the bending of steel beams, where both used total stations.

Martins and Silva (2017), using robotic total stations, demonstrated the superiority of accuracy of the Minimum Distances Method compared to Polar Method for short distances, obtaining a 3D precision below $\pm 1.3 \mathrm{~mm}$ for a target that was at a distance of approximately 23 meters from the measuring stations.

\subsection{Mathematical Formulation}

The mathematical modeling of the 3D optical intersection method using the Minimum Distances Method (Martins \& Silva, 2017) is based on Vector Calculation concepts, for the determination of the straight lines, on which the lines of sight are supported. The intersection point is obtained by the adjustment of the parametric model of the method of least squares.

The $n$ straight lines $\left(l_{i}\right)$ that support the sight lines from the stations (known vertices) are given by equation 1 . They are obtained from the origin point, that is, the optical center $\left(\mathrm{CO}_{i}\right)$ of the instrument and the unit vector $\boldsymbol{v}_{i}$, giving the direction to the point $\boldsymbol{P}$ multiplied by a scale factor $\left(t_{i}\right)$, also called as slant distance.

$$
l_{i}: \quad P=C O_{i}+t_{i} \cdot v_{i}, \quad t_{i} \in \mathbb{R}
$$


The components $\left(a_{i}, b_{i}, c_{i}\right)$ of vector $v_{i}$, known as cosine directors, are calculated using equations 2, 3 and 4, respectively, from the measurement of azimuth $A z_{i}$ (clockwise angle in relation to the north of the reference system) and from the zenith angle $Z_{i}$ to point $P$.

$$
\begin{aligned}
& a_{i}=\sin \left(Z_{i}\right) \cdot \sin \left(A z_{i}\right) \\
& b_{i}=\sin \left(Z_{i}\right) \cdot \cos \left(A z_{i}\right) \\
& c_{i}=\cos \left(Z_{i}\right)
\end{aligned}
$$

Knowing the slant distances $t_{\mathrm{i}}$ for each straight line, the coordinates of the points $P$ can be determined from equations 5, 6 and 7 .

$$
\begin{aligned}
& x_{P}=x_{c o_{i}}+t_{i} \cdot a_{i} \\
& y_{P}=y_{c o_{i}}+t_{i} \cdot b_{i} \\
& z_{P}=z_{c o_{i}}+t_{i} \cdot c_{i}
\end{aligned}
$$

For the calculation of the spatial coordinates of point $P$, therefore, it is necessary to have at least two known observation stations and in different positions, allowing to work with a system of overdetermined equations, corresponding to the unknowns (or parameters) that are the coordinate values $\left(x_{P}, y_{P}, z_{P}\right)$ and the slant distances $t_{1}, \ldots, t_{n}$.

Thus, for the coordinates of the $n$ stations, the vector of residues $V$ is given by equation 8 .

$$
V=\left[\begin{array}{c}
x_{P}-x_{C O_{1}}-t_{1} \cdot a_{1} \\
y_{P}-y_{C_{1}}-t_{1} \cdot b_{1} \\
z_{P}-z_{C O_{1}}-t_{1} \cdot c_{1} \\
\vdots \\
x_{P}-x_{C O_{n}}-t_{n} \cdot a_{n} \\
y_{P}-y_{C O_{n}}-t_{n} \cdot b_{n} \\
z_{P}-z_{C O_{n}}-t_{n} \cdot c_{n}
\end{array}\right]
$$

The $\boldsymbol{\varphi}$ function, corresponding to the sum of the squared distances of a target point to the straight lines that supports the line of sight, which is given by equation 9:

$$
\varphi=V^{T} \cdot V=(A X-L)^{T}(A X-L)
$$

The unknown parameters $X$, which are composed of the intersection point coordinates, as well as the slat distance, the vector with the coordinates for the optical centers $L$, and the design matrix $A$ (Jacobian matrix in relation to the parameters) are expressed by equations 10,11 , and 12 , respectively:

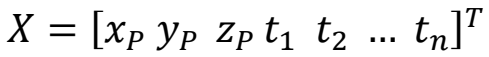

$$
\begin{aligned}
& L=\left[\begin{array}{llllllllll}
x_{\mathrm{CO}_{1}} & y_{\mathrm{CO}_{1}} z_{\mathrm{CO}_{1}} & x_{\mathrm{CO}_{2}} & y_{\mathrm{CO}_{2}} z_{\mathrm{CO}_{2}} & \ldots & x_{\mathrm{CO}_{n}} & y_{\mathrm{CO}_{n}} z_{\mathrm{CO}_{n}}
\end{array}\right]^{T}
\end{aligned}
$$






The best estimator is obtained when $\boldsymbol{\varphi}$ is minimal, that is, when the gradient of equation 9 in relation to its parameters is equal to zero (equation 13 ):

$$
\nabla \varphi(\hat{X})=0
$$

Thus, according to Gemael (1994), the vector of the estimated parameters $\widehat{\boldsymbol{X}}$ can be calculated by the following matrix resolution (equation 14 ):

$$
\hat{X}=\left(A^{T} A\right)^{-1} A^{T} L
$$

By considering the weights through matrix $W$, the equation 14 can be expressed by equation 15 :

$$
\hat{X}=\left(A^{T} W A\right)^{-1} A^{T} W L
$$

For the Minimum Distance Method, the weight matrix $W$ can be calculated from the precision of the coordinates of the measuring stations, or considering the precision of horizontal and vertical angular measurements, or even taking advantage of the slant distances obtained in the first adjustment (without weight) and applying them in a second adjustment.

Equation 16 corresponds to the weight matrix $W$ calculated from the estimated slant distances $t_{1}, \ldots, t_{n}$, whose diagonal elements correspond to the inverse of the distance. In this case, this weight matrix gives more weight to the closest observations and less weight to the more distant ones.

$$
W=\left[\begin{array}{ccccccc}
1 / t_{1} & 0 & 0 & \ldots & 0 & 0 & 0 \\
0 & 1 / t_{1} & 0 & \ldots & 0 & 0 & 0 \\
0 & 0 & 1 / t_{1} & \ldots & 0 & 0 & 0 \\
\vdots & \vdots & \vdots & \ddots & \vdots & \vdots & \vdots \\
0 & 0 & 0 & \ldots & 1 / t_{n} & 0 & 0 \\
0 & 0 & 0 & \ldots & 0 & 1 / t_{n} & 0 \\
0 & 0 & 0 & \ldots & 0 & 0 & 1 / t_{n}
\end{array}\right]
$$


The "posteriori" variance or precision of the determinations is determined by equation 17:

$$
\hat{\sigma}_{0}^{2}=\frac{V^{T} W V}{e-p}
$$

in which $e$ is the number of observation equations and $p$ is the number of parameters, which can be calculated according to the quantity $n$ of observation stations using equations 18 and 19:

$$
\begin{aligned}
& e=3 \times n \\
& p=3+n
\end{aligned}
$$

The calculation of the Variance-Covariance Matrix $\left(\sum \boldsymbol{X}\right)$ of the parameters is determined by equation 20:

$$
\sum X=\hat{\sigma}_{0}^{2}\left(A^{T} W A\right)^{-1}
$$

where the $\sum \boldsymbol{X}$ matrix's diagonal corresponds to the variances of the estimated parameters of $\boldsymbol{X}_{P_{\text {, }}}$ $y_{P}, z_{p}, t_{1}, \ldots, t_{n}$.

\section{Methodology}

The Minimum Distances Method was applied in the geodetic survey of inaccessible corners from the top of SUDENE building, which is located on the side of the Governador Mário Covas highway (BR-101), today in the Campus of the Federal University of Pernambuco (UFPE), in Recife-PE (Figure 1).


Figure 1: (a) Area of study; (b) Location map in the municipality of Recife; and (c) Location map of the state of Pernambuco, Brazil. 
For the survey of the immediate support points (stations used for the subsequent measurements of the corners of the building), four GNSS dual frequency (L1/L2) Topcon receivers (Figure 2), one model Hiper $V$ and other three Hyper Lite ${ }^{+}$, were used. And the observations were processed in the Topcon Tools v.8.2 software by the static relative positioning method. The GNSS baselines were processed considering L1/L2 observations, the network was adjusted, and quality control was performed.

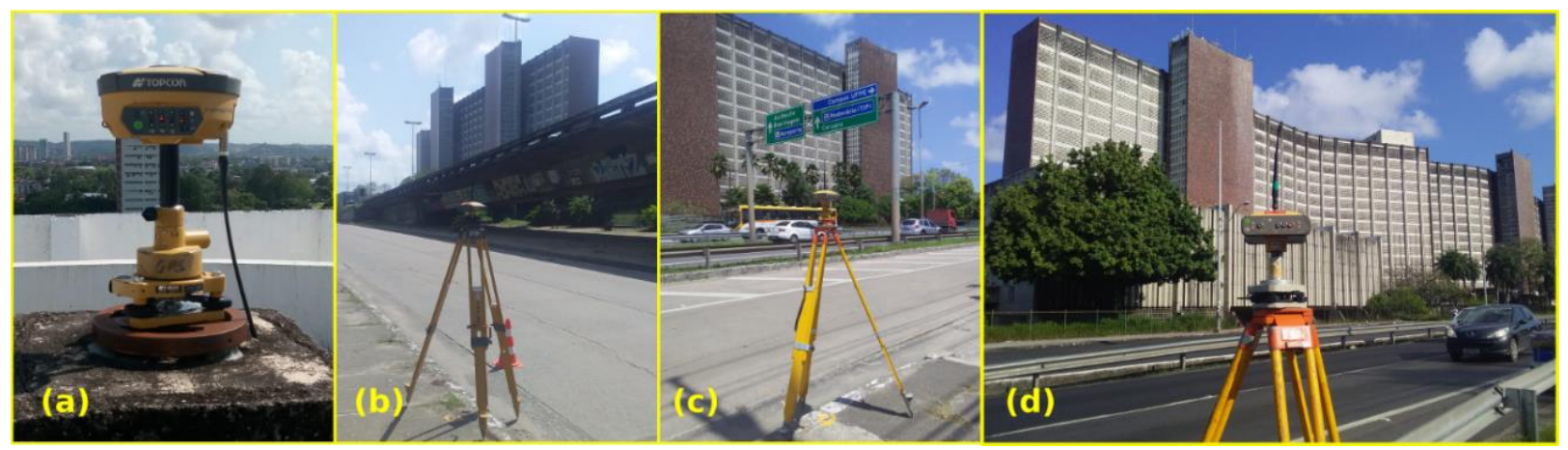

Figure 2: (a) GNSS Topcon Hiper V receiver at SAT GPS station 91551; (b), (c) and (d) GNSS Topcon Hiper Lite ${ }^{+}$receivers measuring the immediate support points (P1, P2 and P3 respectively) near the building.

Three receivers were used in the survey of the closed polygonal defined by the immediate support points, implanted around the building (Figure 3), occupying them alternately so that always two receivers were double-tracking the same baseline, combined with the technique popularly known as frog jumping, the latter discussed in Silva et al. (2003).

IBGE (2017) recommends, for the length of the baselines of this work, the tracking of 5 to 10 minutes in each station to obtain precision of $5-10 \mathrm{~mm}+1 \mathrm{ppm}$. However, the tracking time performed for the stations was from 1 to 2 hours. This tracking time much longer than that specified allowed greater rigidity in the geometric figures formed by the GNSS receivers for the measurement of the vertices around the building and the application of the GNSS network method.

The fourth GNSS receiver tracked the passive station SAT GPS 91551 located on the roof of the administration building of the Center for Technology and Geosciences (CTG) (Figure 2(a) and Figure 3) of the UFPE. In addition to the four receivers, data from the active GNSS station of the Brazilian Continuous Monitoring Network (RBMC), called PERC, which is located in the building of the Federal Institute of Pernambuco (IFPE) were used. This procedure allowed a greater redundancy of data in the GNSS network processing (Figure 3), ensuring the accuracy of the coordinates of the stations around the building (Monico, 2007). 


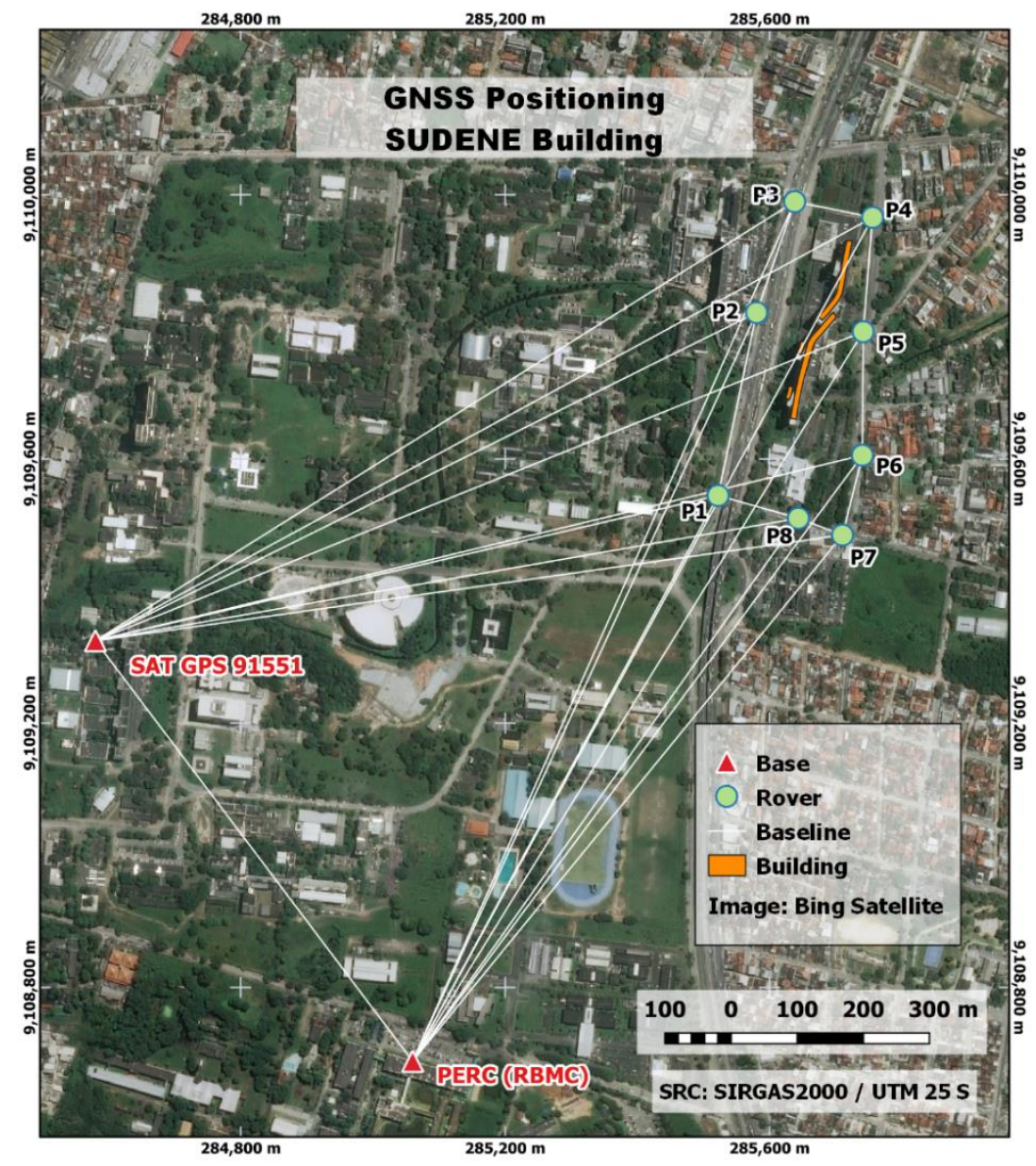

Figure 3: GNSS network to survey the support points.

The Geodetic coordinates, in SIRGAS2000, of the immediate support points calculated in the processing of GNSS data along with the respective precisions are given in Table 1.

Table 1: Geodetic coordinates of the support points and their precisions

\begin{tabular}{c|c|c|c|c|c|c}
\hline Pnt & Longitude & Latitude & $\begin{array}{c}\text { Altitude } \\
\text { Elips. }(m)\end{array}$ & $\begin{array}{c}\text { StdDev } \\
\text { Lon }(m)\end{array}$ & $\begin{array}{c}\text { StdDev } \\
\text { Lat }(m)\end{array}$ & $\begin{array}{c}\text { StdDev } \\
h(m)\end{array}$ \\
\hline P1 & $-34^{\circ} 56^{\prime} 46.16538^{\prime \prime}$ & $-8^{\circ} 03^{\prime} 03.89423^{\prime \prime}$ & 2.869 & \pm 0.002 & \pm 0.002 & \pm 0.004 \\
\hline P2 & $-34^{\circ} 56^{\prime} 44.21872^{\prime \prime}$ & $-8^{\circ} 02^{\prime} 54.89110^{\prime \prime}$ & 2.643 & \pm 0.002 & \pm 0.002 & \pm 0.004 \\
\hline P3 & $-34^{\circ} 56^{\prime} 42.31334^{\prime \prime}$ & $-8^{\circ} 02^{\prime} 49.43663^{\prime \prime}$ & 2.501 & \pm 0.002 & \pm 0.002 & \pm 0.004 \\
\hline P4 & $-34^{\circ} 56^{\prime} 38.46836^{\prime \prime}$ & $-8^{\circ} 02^{\prime} 50.23223^{\prime \prime}$ & 2.528 & \pm 0.002 & \pm 0.002 & \pm 0.004 \\
\hline P5 & $-34^{\circ} 56^{\prime} 38.95980^{\prime \prime}$ & $-8^{\circ} 02^{\prime} 55.85719^{\prime \prime}$ & 2.112 & \pm 0.002 & \pm 0.002 & \pm 0.004 \\
\hline P6 & $-34^{\circ} 56^{\prime} 39.02798^{\prime \prime}$ & $-8^{\circ} 03^{\prime} 01.94368^{\prime \prime}$ & 2.715 & \pm 0.002 & \pm 0.002 & \pm 0.004 \\
\hline P7 & $-34^{\circ} 56^{\prime} 40.02677^{\prime \prime}$ & $-8^{\circ} 03^{\prime} 05.86807^{\prime \prime}$ & 2.261 & \pm 0.002 & \pm 0.002 & \pm 0.005 \\
\hline P8 & $-34^{\circ} 56^{\prime} 42.20542^{\prime \prime}$ & $-8^{\circ} 03^{\prime} 05.03028^{\prime \prime}$ & 3.168 & \pm 0.002 & \pm 0.002 & \pm 0.004 \\
\hline
\end{tabular}

For the calculation of 3D coordinates, the geodetic coordinates were transformed to the Local Geodetic System (LGS). The LGS compared to the UTM projection system has the advantage of eliminating the inconsistency of the projection model when adjusting the observations obtained with the total station (Silva et al., 2015; Garnés, 1998; Garnés et al., 2005; Souza, 2012). That is, the adoption of LGS avoids any type of deformation resulting from the UTM projection system.

For the transformation of the three-dimensional cartesian geodetic coordinates of the Global Geodetic System to the Topocentric Coordinates in the LGS, the SIRGAS2000 major axis and 
flattening parameters were adopted and the transformations established in the national standards (IBGE, 1989; IBGE, 2005) and the method of translations and rotations discussed in (Torge, 2001; Garnés, 1998; Garnés et al., 2005; Dal'Forno et al., 2010).

The LGS consists of an orthogonal axis coordinate reference system $(E, N, U)$, where the " $N$ " axis points towards the Geodetic north, the "E" axis points towards the east direction, both contained in the perpendicular plane normal to the ellipsoid that passes through a point arbitrated as the origin of the system, with the " $U$ " axis coinciding with this normal (Simões et al., 2017).

In this work, the origin of the LGS was defined at the point of longitude $34^{\circ} 56^{\prime} 41.82180^{\prime \prime} \mathrm{W}$ and latitude $8^{\circ} 02^{\prime} 57.96154^{\prime \prime} S$, centroid of the support points measured by GNSS and geodetic altitude (ellipsoidal) $h=2.600 \mathrm{~m}$, average of the altitudes of the support points.

The topocentric coordinates $(E, N, U)$ in the LGS considered of the Stations are given by Table 2 . The altitudes of the optical center $\left(U_{C O}\right)$ corresponding to the altitudes of the stations plus their respective distances to the $\mathrm{CO}$ of the equipment (total station height).

Table 2: Topocentric Coordinates $(E, N, U)$ of stations and altitudes of $\mathrm{CO}\left(U_{C O}\right)$

\begin{tabular}{c|c|c|c|c}
\hline Station & $E(m)$ & $N(m)$ & $U(m)$ & $U_{C O}(m)$ \\
\hline P1 & 149867.058 & 249817.768 & 0.265 & 1.825 \\
\hline P2 & 149926.663 & 250094.354 & 0.042 & 1.530 \\
\hline P3 & 149985.005 & 250261.921 & -0.104 & 1.428 \\
\hline P4 & 150102.736 & 250237.479 & -0.077 & 1.313 \\
\hline P5 & 150087.688 & 250064.674 & -0.489 & 0.901 \\
\hline P6 & 150085.600 & 249877.691 & 0.114 & 1.559 \\
\hline P7 & 150055.018 & 249757.128 & -0.344 & 1.346 \\
\hline P8 & 149988.309 & 249782.867 & 0.565 & 1.962 \\
\hline
\end{tabular}

The survey of the polygonal around the building was carried out with a Total Station using forced centering, occupying the support points. The equipment used was the Topcon Total Station (Figure 4), model GPT 3200 with angular precision of $\pm 5^{\prime \prime}$ and linear precision of $\pm(5 \mathrm{~mm}+5 *$ Dppm). In this activity, the observations of the points located on the corners of the top of the building were carried out simultaneously, measuring vertical zenith angles and horizontal directions of the inaccessible points (corners of the building) with direct and inverse measurements with two repetitions.

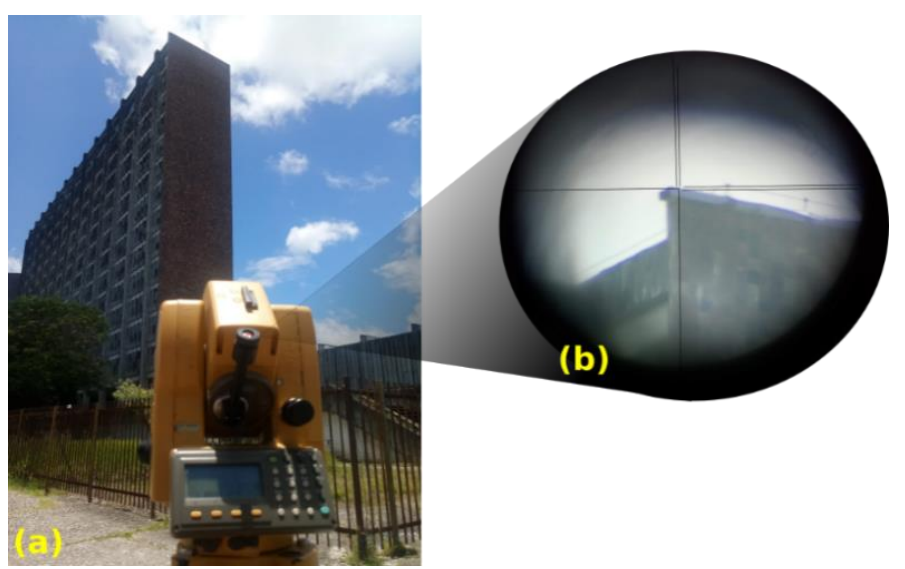

Figure 4: (a) Measurement of Corner Q4 of the SUDENE building with a Total Station from point P4. (b) Corner Q4 of the building. 
In total, six corners of the building were measured, as shown in Figure 5 (a), and the Q6 corner (Figure 5 (b)) was chosen for this study because it is the object point with the highest number of sight lines, thus enabling, further analysis of the adjustment using the Minimum Distance Method.
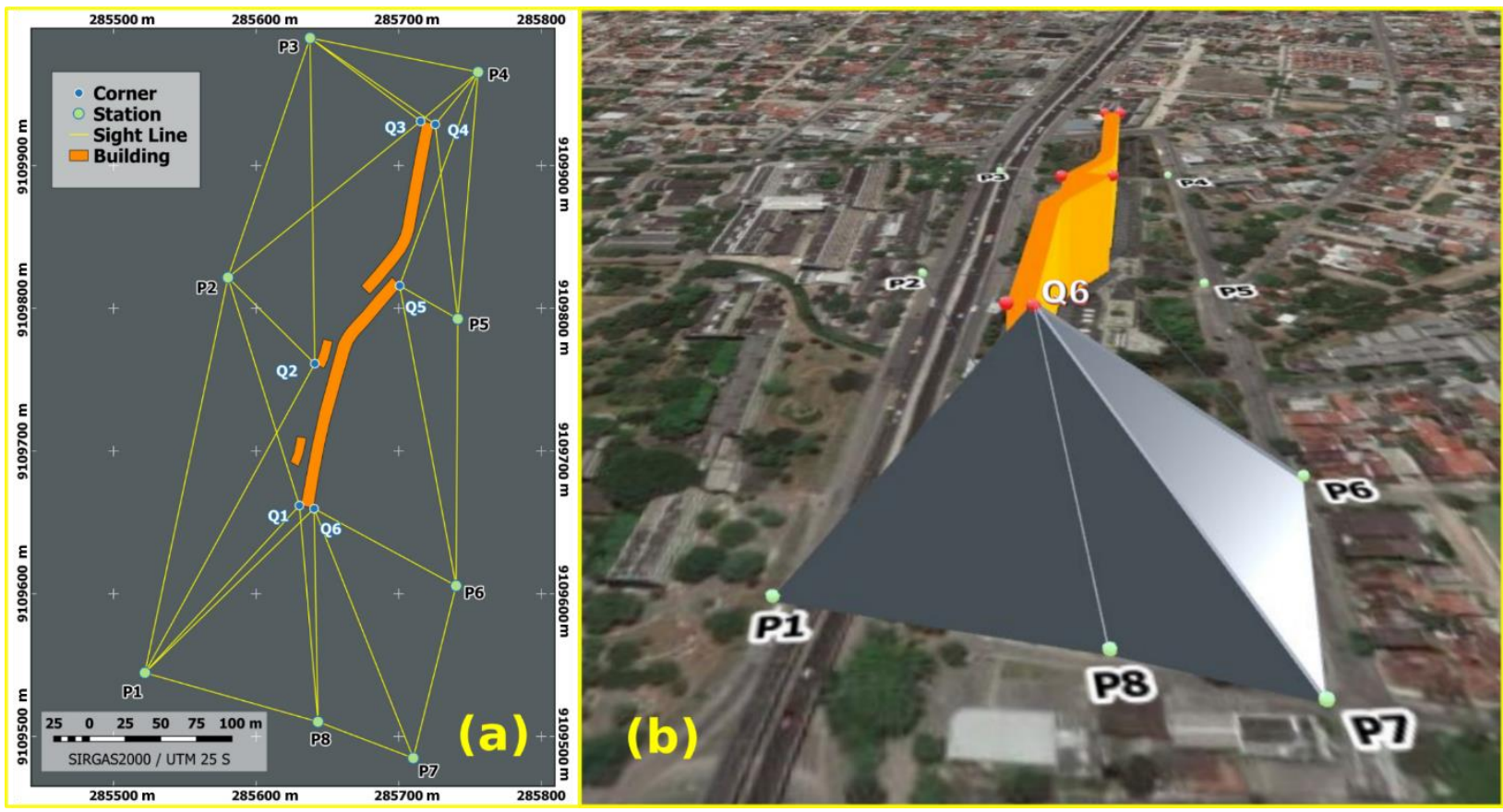

Figure 5: (a) Corners to be measured in the top of SUDENE building; (b) Corner Q6 studied in this work.

Therefore, the coordinates of Q6 were estimated from the observations of azimuth and zenithal vertical angle presented in Table 3 with respective precisions.

Table 3: Average and standard deviation of azimuth and vertical zenith angle measured from stations to corner Q6

\begin{tabular}{c|c|c|c|c}
\hline Station & Azimuth $(A z)$ & $\sigma(A z)$ & Zenital Angle $(Z)$ & $\sigma(Z)$ \\
\hline P1 & $46^{\circ} 10^{\prime} 06.37^{\prime \prime}$ & $\pm 5.9^{\prime \prime}$ & $72^{\circ} 24^{\prime} 22.25^{\prime \prime}$ & $\pm 5.6^{\prime \prime}$ \\
\hline P8 & $359^{\circ} 12^{\prime} 12.21^{\prime \prime}$ & $\pm 4.3^{\prime \prime}$ & $70^{\circ} 43^{\prime} 01.75^{\prime \prime}$ & $\pm 7.6^{\prime \prime}$ \\
\hline P7 & $338^{\circ} 32^{\prime} 59.40^{\prime \prime}$ & $\pm 7.8^{\prime \prime}$ & $74^{\circ} 17^{\prime} 54.17^{\prime \prime}$ & $\pm 6.3^{\prime \prime}$ \\
\hline P6 & $298^{\circ} 46^{\prime} 22.93^{\prime \prime}$ & $\pm 7.4^{\prime \prime}$ & $65^{\circ} 04^{\prime} 27.25^{\prime \prime}$ & $\pm 8.0^{\prime \prime}$ \\
\hline
\end{tabular}

The standard deviations achieved for the observations of azimuth and vertical zenith angle are emphasized since the target inaccessible point, located at the top of the structure of the SUDENE building, is a natural point materialized by the sides of the facade in the shape of a corner.

For the processing of observations, the tool "Estimate 3D Coordinates" developed in Python for QGIS (PyQGIS) was used in order to execute the Minimum Distances Method. This tool is free software developed to apply and test the survey method discussed in this work, whose code is available on GitHub for download at the reference link (França, 2020).

Figure 6 presents the input parameters of the QGIS tool and how they must be filled in for the perfect execution of the algorithm, observing the data separation patterns, either by comma or semicolon. 


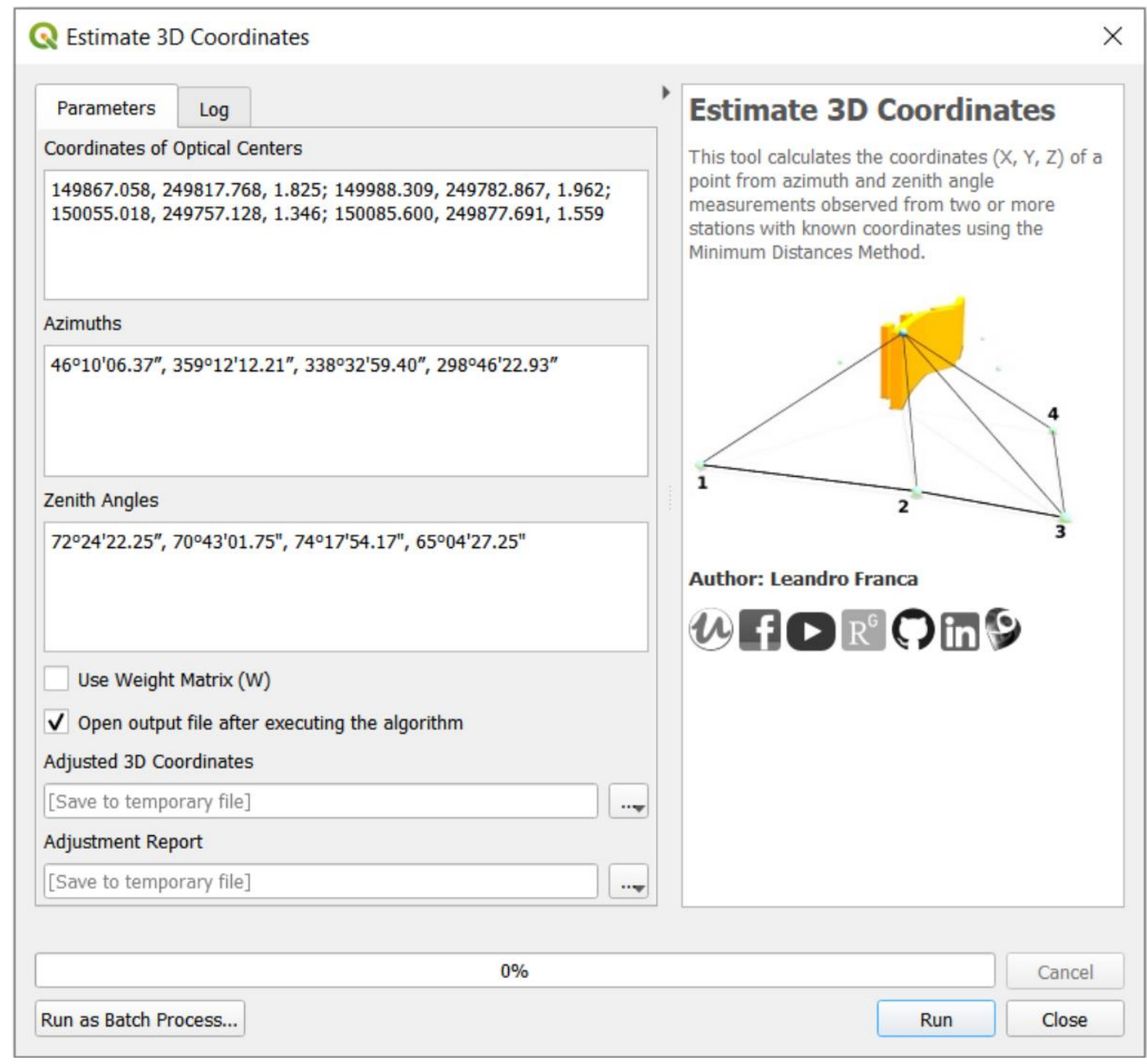

Figure 6: "Estimate 3D Coordinates" QGIS tool.

The output files correspond to a spreadsheet in Microsoft Excel XLS format with the coordinates adjusted for the observed 3D point; and an HTML file with details of the adjustment, enabling quality control through analysis of the residuals and posteriori variance.

In this work, different combinations of the 4 stations P1, P8, P7 and P6 (Figure 5.b) were analyzed, in order to allow the comparison of coordinates and precision in three stages: the first with 2 stations, performing the combinations " 4 choose 2" $\left(C_{4,2}\right)$; the second with 3 stations, making the combinations " 4 choose 3 " $\left(C_{4,3}\right)$; and the last one, using all data from the 4 stations, which is the same as the combination " 4 choose 4 " $\left(C_{4,4}\right)$.

Descriptive statistics were used to evaluate the results in order to compare the three types of combination of the input data, in addition, graphs were generated to analyze the variance both in planimetry $(E, N)$ and in altimetry $(U)$.

For all possible combinations, the spherical positional error was calculated by equation 21, considering the coordinates' variances obtained from the Covariance Matrix's diagonal.

$$
\sigma_{\text {sphere }}=\sqrt{\sigma_{E}^{2}+\sigma_{N}^{2}+\sigma_{U}^{2}}
$$




\section{Results and Discussions}

For each combination, the "Estimate 3D Coordinates" tool generated a report in HTML format, similar to the example in Figure 7, with the information about the adjustment by the method of least squares, in order to identify discrepancies through the residual vector and possible cases of gross errors.

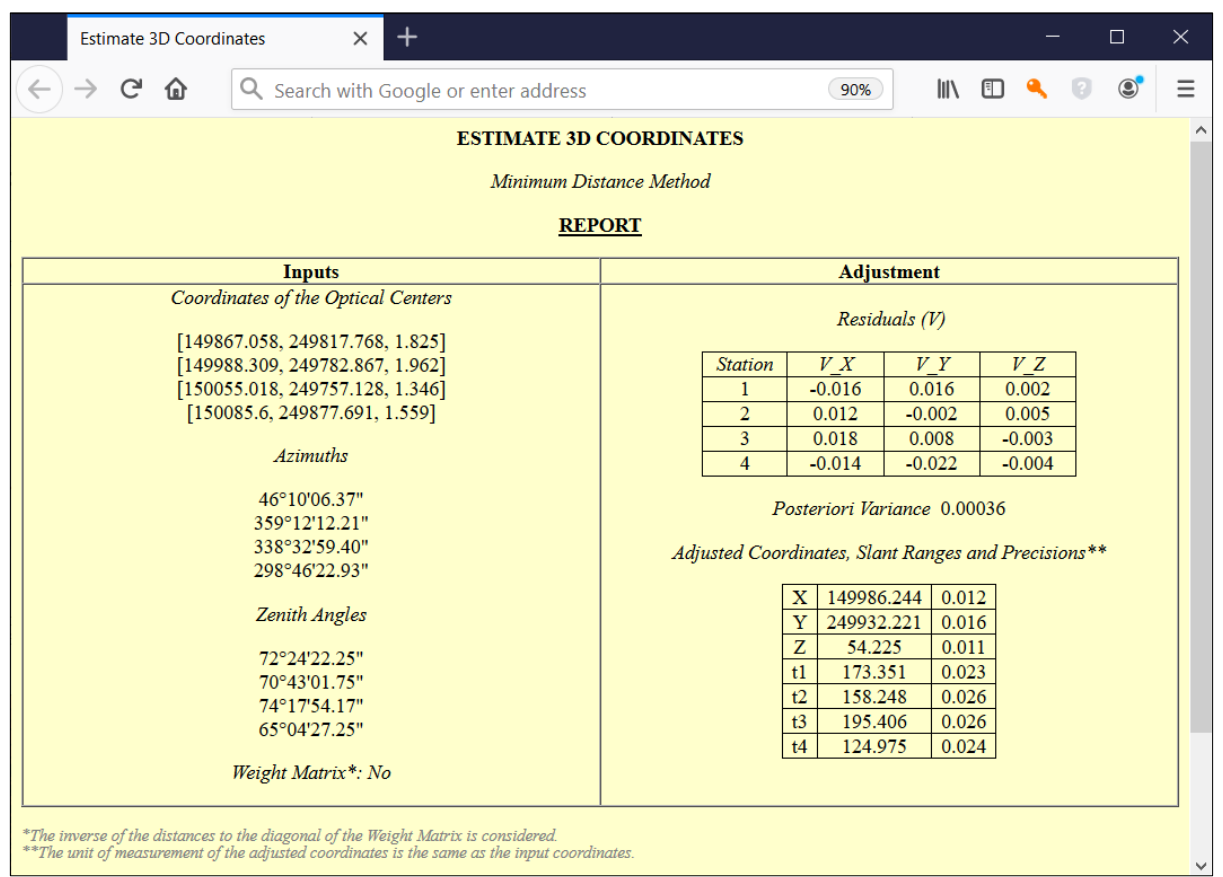

Figure 7: Adjustment report.

Table 4 presents the results for the combinations between two stations $\left(C_{4,2}\right)$ and Table 5 presents the results of the possible combinations between three stations $\left(C_{4,3}\right)$. Table 6 , in turn, presents the results of using the adjustment with the observations of the four stations.

Table 4: Results for combinations $C_{4,2}$

\begin{tabular}{c|c|c|c|c|c|c}
\hline \multirow{2}{*}{ Combination } & \multicolumn{3}{|c|}{ Coordinates $(\boldsymbol{m})$} & \multicolumn{3}{c}{ Precisions (m) } \\
\cline { 2 - 7 } & $\boldsymbol{E}$ & $\boldsymbol{N}$ & $\boldsymbol{U}$ & $\boldsymbol{\sigma} \boldsymbol{E}$ & $\boldsymbol{\sigma} \boldsymbol{N}$ & $\boldsymbol{\sigma U}$ \\
\hline P1-P8 & 149986.233 & 249932.179 & 54.208 & \pm 0.004 & \pm 0.007 & \pm 0.004 \\
\hline P8-P7 & 149986.232 & 249932.202 & 54.219 & \pm 0.008 & \pm 0.031 & \pm 0.011 \\
\hline P7-P6 & 149986.205 & 249932.272 & 54.251 & \pm 0.011 & \pm 0.013 & \pm 0.008 \\
\hline P1-P7 & 149986.238 & 249932.183 & 54.216 & \pm 0.003 & \pm 0.005 & \pm 0.003 \\
\hline P1-P6 & 149986.279 & 249932.229 & 54.225 & \pm 0.012 & \pm 0.010 & \pm 0.009 \\
\hline P8-P6 & 149986.233 & 249932.258 & 54.238 & \pm 0.007 & \pm 0.008 & \pm 0.006 \\
\hline
\end{tabular}

Table 5: Results for combinations $C_{4,3}$

\begin{tabular}{c|c|c|c|c|c|c}
\hline \multirow{2}{*}{ Combination } & \multicolumn{3}{|c|}{ Coordinates $(m)$} & \multicolumn{3}{c}{ Precisions (m) } \\
\cline { 2 - 7 } & $E$ & $\boldsymbol{N}$ & $\boldsymbol{U}$ & $\boldsymbol{\sigma} \boldsymbol{E}$ & $\boldsymbol{\sigma} \boldsymbol{N}$ & $\boldsymbol{\sigma U}$ \\
\hline P1-P8-P7 & 149986.236 & 249932.184 & 54.213 & \pm 0.004 & \pm 0.007 & \pm 0.004 \\
\hline P8-P7-P6 & 149986.224 & 249932.257 & 54.240 & \pm 0.009 & \pm 0.014 & \pm 0.008 \\
\hline P1-P8-P6 & 149986.254 & 249932.227 & 54.225 & \pm 0.014 & \pm 0.017 & \pm 0.013 \\
\hline P1-P7-P6 & 149986.251 & 249932.220 & 54.226 & \pm 0.017 & \pm 0.019 & \pm 0.015 \\
\hline
\end{tabular}


Table 6: Result for the adjustment of all observations $C_{4,4}$

\begin{tabular}{c|c|c|c|c|c|c}
\hline \multirow{2}{*}{ Combination } & \multicolumn{3}{|c|}{ Coordinates (m) } & \multicolumn{3}{c}{ Precisions (m) } \\
\cline { 2 - 7 } & $E$ & $N$ & $U$ & $\sigma \boldsymbol{E}$ & $\boldsymbol{\sigma} \boldsymbol{N}$ & $\boldsymbol{\sigma} \boldsymbol{U}$ \\
\hline P1-P8-P7-P6 & 149986.244 & 249932.221 & 54.225 & \pm 0.012 & \pm 0.016 & \pm 0.011 \\
\hline
\end{tabular}

Table 7 shows the descriptive statistics of the resulting coordinates presented in Tables 4 and 5 , where it can be seen that the average of their coordinates is close to the coordinates obtained in the processing with all the observations, given in Table 6. Furthermore, the decrease of variance is confirmed, as the number of stations increases.

Table 7: Statistics of coordinates calculated in combinations between stations

\begin{tabular}{c|c|l|l|l|l|l}
\hline \multirow{2}{*}{ Statistics } & \multicolumn{4}{|c|}{$C_{\mathbf{4}}^{\mathbf{2}}$} & \multicolumn{3}{c}{$\boldsymbol{C}_{\mathbf{4}}^{\mathbf{3}}$} \\
\cline { 2 - 7 } & $E(m)$ & $N(m)$ & $U(m)$ & $E(m)$ & $N(m)$ & $U(m)$ \\
\hline Average & 149986.237 & 249932.221 & 54.226 & 149986.241 & 249932.222 & 54.226 \\
\hline Minimum & 149986.205 & 249932.179 & 54.208 & 149986.224 & 249932.184 & 54.213 \\
\hline Maximum & 149986.279 & 249932.272 & 54.251 & 149986.254 & 249932.257 & 54.240 \\
\hline Amplitude & 0.074 & 0.093 & 0.043 & 0.030 & 0.073 & 0.027 \\
\hline $\begin{array}{c}\text { Standard } \\
\text { Deviation }\end{array}$ & \pm 0.022 & \pm 0.036 & \pm 0.014 & \pm 0.012 & \pm 0.026 & \pm 0.010 \\
\hline
\end{tabular}

Figure 8 shows the topocentric coordinates of the points in the plane $(E, N)$ with the respective circumferences of radius equal to the spherical error calculated by equation 21 .

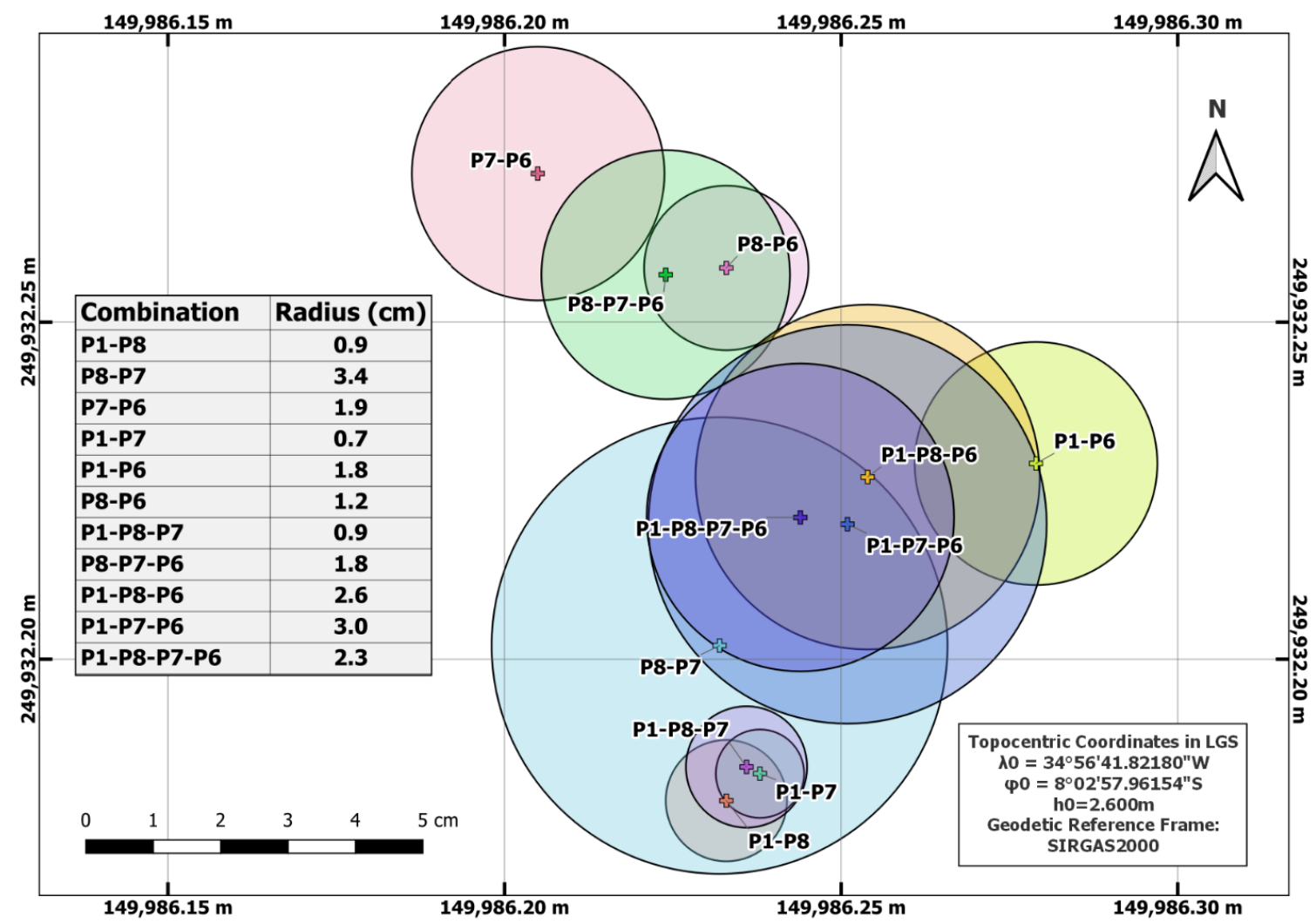

Figure 8: Radius for spherical precisions. 
Analyzing the results of Figure 8 , it is allowed to conclude that, for all combinations, the spherical positional error is less than \pm 8 centimeters, being in accordance with the established in the rules of urban land regularization in Brazil (BRASIL, 2018).

However, from the graphical interpretation, it was possible to identify that the best results were obtained in the combinations "P1-P8", "P1-P7" and "P1-P8-P7", achieving spherical precision better than $\pm 1 \mathrm{~cm}$. The use of the "P6" station for all combinations implied a decrease in precision.

Thus, a refinement of the results can be considered, admitting the combination "P1-P8-P7" as the best result, instead of the adjustment with all the observations "P1-P8-P7-P6".

In other words, the increase in observation stations did not necessarily collaborate the improvement of quality. This situation can be justified by the fact that the point was not signaled (with a prism, for instance) and the operator needed to interpret the corner of the building from different angles.

The decision of choosing the combination "P1-P8-P7" can be corroborated by analyzing the altimetric precision $(\sigma \cup)$ through Figure 9, where all the calculated altitudes and the respective precision for each combination are plotted of the building's corner Q6.

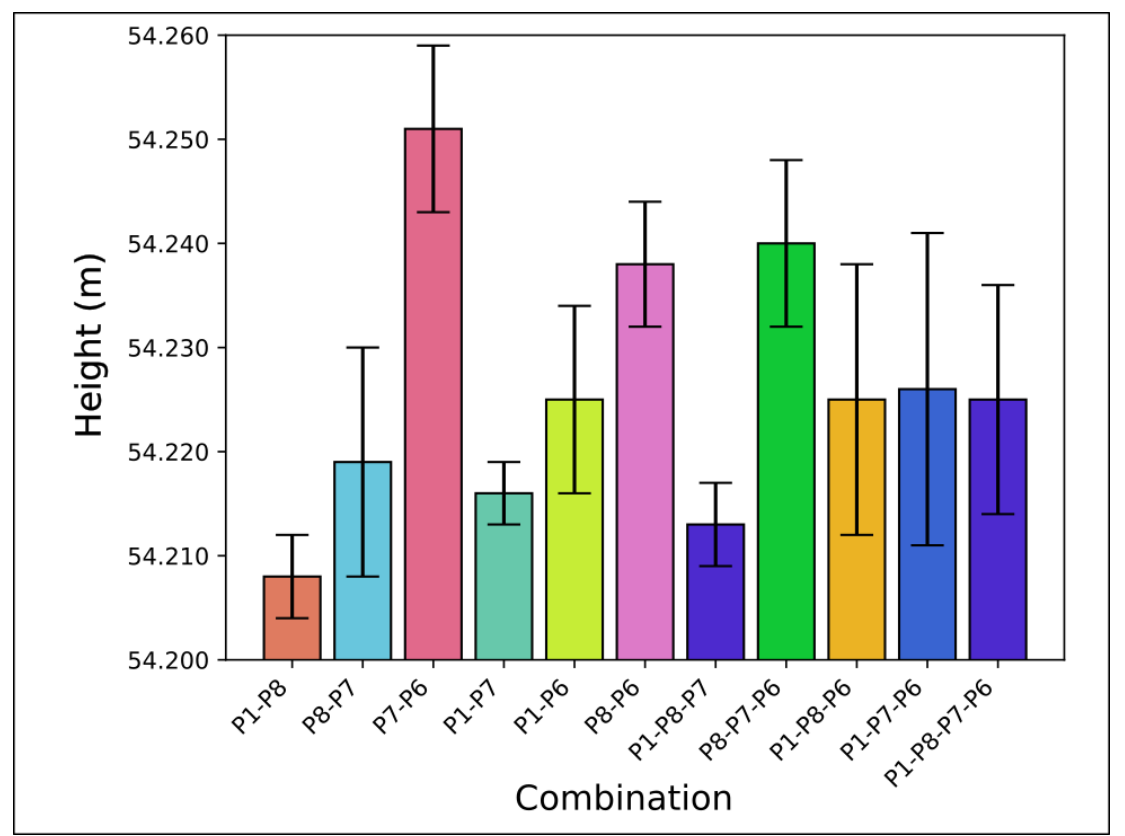

Figure 9: Building height and precision calculated for each combination.

It is noteworthy that the advantage of considering the adjusted coordinates with several observations is to ensure the redundancy of observations, making the model more robust (Gemael, 1994; Martins \& Silva, 2017), that is, the overabundance of measurements offers more confidence and quality in the acquisition of information, a preponderant factor for execution, monitoring and decision-making in the most delicate tasks and works of modern engineering (Martins, 2019).

Gross errors can be inspected through the residual vector, but it is recommended to perform the Chi-Square $\chi^{2}$ test to check the quality of the adjustment and employ techniques to automatically test the existence of these errors, such as the "data snooping" test (Monico \& Silva, 2003; Mendonça et al., 2010).

In this work, all adjustments were made without using the weight matrix. The use of the weight matrix did not show significant improvements in the precision of the results. It is assumed that this 
situation is related to the fact that the slant distances used in the matrix are in the same order of magnitude, but further studies also involving the precision of the coordinates of the stations, and the precision of the angular measurements (azimuth and zenith angle) in different situations are necessary.

In Geographic Information Systems (GIS), the use of topocentric coordinates is not common. Therefore, the transformation of the final adjusted coordinates in the topocentric system to a geodetic system becomes necessary to be loaded in cadastral GIS.

Thus, Table 8 presents the coordinates and respective precision of the Q6 corner adjusted from the observations of stations P1, P8 and P7, transformed from the topocentric system to the geodetic system SIRGAS2000.

Table 8: Geodetic coordinates in SIRGAS2000 of the adjusted Q6 corner

\begin{tabular}{c|c|c|c|c|c}
\hline Longitude $(\lambda)$ & $\sigma(\lambda) m$ & Latitude $(\varphi)$ & $\sigma(\varphi) m$ & Altitude $(h)$ & $\sigma(h) m$ \\
\hline $34^{\circ} 56^{\prime} 42.27312^{\prime \prime} \mathrm{W}$ & \pm 0.004 & $8^{\circ} 03^{\prime} 00.16985^{\prime \prime} \mathrm{S}$ & \pm 0.007 & $56.813 \mathrm{~m}$ & \pm 0.004 \\
\hline
\end{tabular}

\section{Conclusion}

The methodology of this work, which integrated GNSS data with the terrestrial planialtimetric measurements collected from Total Station, proved to be efficient for Geodetic surveys of large structures, such as the SUDENE building, achieving spherical precisions better than $\pm 1.0 \mathrm{~cm}$.

In this way, it can be concluded that the results of this work serve as a reference for the assessment of the 3D positional quality of geodetic surveys of buildings for the urban land register (cadastre) in Brazil, regulated by Decree-Law no 9.310 (BRASIL, 2018), considering that the spherical precision achieved is better than required by law $( \pm 8 \mathrm{~cm})$.

Another relevance of this work is the implementation of the Minimum Distance Method algorithm in a free and open computational tool (Python for the QGIS3 software), made available to the entire scientific community through GitHub. This tool was developed to process observations of any number $n(n \geq 2)$ of known stations, applying the 3D optical intersection method and adjustment by the Least Squares Method, following the mathematical modeling presented in item 2 of this work.

With regard to the control of engineering structures that require better precision than those achieved in this work, new research can be developed considering a model that includes the effects of refraction and curvature of the Earth, considering that variations in atmospheric conditions alter the speed of propagation of electromagnetic waves and consequently cause systematic errors (Gomes et al., 2007).

In this work, only the precision of the adjustment was evaluated, considering the target was an inaccessible point, however, future studies may apply the method of minimum distances to a known coordinate point, in order to also evaluate the absolute accuracy of the method (França et al., 2019).

Another important point is that although the result of this work achieves good precision, it is understood that further research is needed with a larger sample and with different types of 
devices, to "quantify" how efficient the method is in different situations, also analyzing the influence of weighting the results through the weight matrix.

Another possibility of deepening this work is to verify the influence of the position of the observation point, because, as Nadal (2000) states, the overabundance of observations is not always sufficient to improve the adjustment, requiring observations that have adequate distances and regular geometries that enable a well-conditioned adjustment solution.

The determination of object-points of building structures using the method presented in this work, also contributes to the study and quality control of topographic surveys performed with drones as well as control of the Digital Surface Model obtained with LiDAR data in urban environments. In these cases, a methodology for evaluating both planimetric and altimetric accuracy is discussed in Cintra \& Nero (2015), Nero et al. (2017), França \& Silva (2018) and França et al. (2019).

\section{REFERENCES}

Allan, A. L. (1996). Surveying in Three Dimensions. Survey Review, v. 33, n. 261, p. 454-460.

Alves, J. L. F. G., da Silva, D. J. N., Gonçalves, M. D. L. A. M., \& Nero, M. A. (2012). Metodologia de ensino para Topografia: Proposta didática para o método de estação livre. Anais do IV Simpósio Brasileiro de Ciências Geodésicas e Tecnologias da Geoinformação. Recife, 1-11.

Ariza-López F. J., Rodríguez-Avi J., Reinoso-Gordo J. F (2019). Quality Control of "As Built" BIM Datasets Using the ISO 19157 Framework and a Multiple Hypothesis Testing Method Based on Proportions. ISPRS International Journal of Geo-Information, v. 8, n. 12, p. 569.

Brasil. Decreto no 9.310, de 15 de março de 2018. Available in: http://www.planalto.gov.br/ccivil_03/_ato2015-2018/2018/decreto/D9310.htm

Cheng, X., Li, Q., Zhou, W., \& Zhou, Z. (2020). External Deformation Monitoring and Improved Partial Least Squares Data Analysis Methods of High Core Rock-Fill Dam (HCRFD). Sensors, 20(2), 444.

Cintra, J. P., \& Nero, M. A. (2015). New method for positional cartographic quality control in digital mapping. Journal of surveying engineering, 141(3), 04015001.

Dal'Forno. G. L, Aguirre. A. J, Hillebrand. F. L, Gregório. F. DE V. (2010). Transformação de coordenadas geodésicas em coordenadas no Plano Topográfico Local pelos métodos da norma NBR 14166:1998 e o de rotações e translações. III Simpósio Brasileiro de Ciências Geodésicas e Tecnologias da Geoinformação Recife. p.1- 7.

De Seixas, A.; Pacheco, A. D. P.; Veiga, L. A. K.; Dos Santos, D. P.; Faggion, P. L. (2007). Uma abordagem geodésica de técnicas ópticas de medição tridimensional para determinação e transporte de alturas em áreas de risco. Boletim de Ciências Geodésicas, v. 13, n. 1, p. 165-185.

De Seixas, A. (2004). Sistema de medição polar à base de teodolitos e definição do método das linhas de grade. Revista Brasileira de Cartografia, v. 2, n. 56. 
De Seixas, A. (2009). Deteç̧ão on-line de deformação por meio de um sistema de Medição 3D à base de Teodolitos- verificação do sistema de medição. Boletim de Ciências Geodésicas, v. 15, n. 1.

De Seixas, A.; Gama, L. F.; Moraes, J. N.; Souza, A. M. B. D. (2014). O estabelecimento de padrões de referência altimétrica utilizando o nivelamento geométrico para a definição de alvos altos e inacessíveis. Boletim de Ciências Geodésicas, v. 20, n. 2, 388-410.

Fawzy, H. E. D. (2019). 3D laser scanning and close-range photogrammetry for buildings documentation: A hybrid technique towards a better accuracy. Alexandria Engineering Journal, 58(4), 1191-1204.

França, L.L.S. (2018). Emprego de Sistema de Informações Geográficas (SIG) no monitoramento e controle de obras. VII Simpósio Brasileiro de Ciências Geodésicas e Tecnologias da Geoinformação, Recife.

França, L. L. S.; Silva, L. F. C. F. (2018). Comparison between the Double Buffer Method and the Equivalent Rectangle Method for the quantification of discrepancies between linear features. Boletim de Ciências Geodésicas, 24(3), 300-317.

França, L. L. S. D., Penha, A. D. L. T. D., \& Carvalho, J. A. B. D. (2019). Comparison between Absolute and Relative positional accuracy assessment-a case study applied to Digital Elevation Models. Boletim de Ciências Geodésicas, 25(1).

França, L.L.S. (2020). Python Script for QGIS: Estimate 3D Coordinates. Available in: https://github.com/LEOXINGU/processing/blob/master/scripts/Estimate3dCoord.py

Garnés, S. J. A Siqueira, V. P Cacho, J. P. (2005) Definição para implantação do Sistema Topográfico Local de Campo Grande - MS e análise das fórmulas da NBR 14.166. IV Colóquio Brasileiro de Ciências Geodésicas - IV CBCG. Curitiba. 6p.

Garnés, S. J. A. (1998). Sistema de Projeção e Orientação das Plantas Topográficas. COBRAC 98 - Congresso Brasileiro de Cadastro Técnico Multifinalitário - UFSC - Florianópolis. 29p.

Gemael, Camil. (1994). Introdução ao ajustamento de observações: aplicações geodésicas. Editora UFPR.

Gomes, J. P.; Veiga, L. A. K.; Dos Santos, D. P.; Faggion, P. L. (2007). Determinação de desníveis de precisão com nivelamento trigonométrico utilizando estação total. Boletim de Ciências Geodésicas, v. 13, n. 1.

Haddad, N. A. (2011). From ground surveying to 3D laser scanner: A review of techniques used for spatial documentation of historic sites. Journal of King Saud University-Engineering Sciences, 23(2), 109-118.

IBGE. (1989). Resolução No 23, de 21 de fevereiro de 1989.

IBGE. (2005). Resolução No 01, de 25 de fevereiro de 2005.

IBGE. (2017). Especificações e Normas para Levantamentos Geodésicos associados ao Sistema Geodésico Brasileiro. Rio de Janeiro. Available in: https://geoftp.ibge.gov.br/metodos_e_outros_documentos_de_referencia/normas/normas_lev antamentos_geodesicos.pdf 
Jung, J., Hong, S., Yoon, S., Kim, J., \& Heo, J. (2016). Automated 3D wireframe modeling of indoor structures from point clouds using constrained least-squares adjustment for as-built BIM. Journal of Computing in Civil Engineering, 30(4), 04015074.

Kahmen, H. (2006). Angewandte Geodäsie: Vermessungskunde. 20ạ edição. Einbeck: Editora De Gruyter.

Mao, S., Lu, M., Shen, X., \& Hermann, U. (2013). Multi-point Concurrent Tracking and surveying in construction field. In ISARC. Proceedings of the International Symposium on Automation and Robotics in Construction (Vol. 30, p. 1). IAARC Publications.

Martins, D. O. (2013). Determinação de coordenadas espaciais a partir do Método das Distâncias Mínimas, Dissertação de Mestrado. Escola de Engenharia de São Carlos - USP, 256 p.

Martins, D. O.; Silva, I. (2017). Avaliação de métodos de determinação de coordenadas espaciais com o uso de estações totais robóticas para monitoramento geodésico de estruturas. In: XXVII Congresso Brasileiro de Cartografia e XXVI Exposicarta. p. 91-95.

Martins, D. O. (2019). Determinações de Coordenadas Espaciais a partir do método multipolar com ajustamento das observações. Revista ReLOGA. Araraquara, v. 1, n. 1.

Mendonça, F. J. B.; Garnés, S. D. A.; Pereira, C. M.; Neto, J. B.; Melo, W. D. A. (2010). Análise do ajustamento por mínimos quadrados de uma trilateração topográfica com injunções nos planos UTM e Topocêntrico. III Simpósio Brasileiro de Ciências Geodésicas e Tecnologias da Geoinformação, p. 001-009.

Mill, Tarvo; ALT, Aivars; Liias, Roode. (2013). Combined 3D building surveying techniquesterrestrial laser scanning (TLS) and total station surveying for BIM data management purposes. Journal of Civil Engineering and Management, v. 19, n. sup1, p. S23-S32.

Monico, J.F.G.; Silva, E.F. (2003). Controle de Qualidade em Levantamentos no Contexto da Lei no 10.267 de 28 de agosto de 2001. In: Série em Ciências Geodésicas. Vol.3 Curitiba: Ed. Edson Aparecido Mitishita.

Monico, J. F. G. (2007). Posicionamento pelo GNSS: descrição, fundamentos e aplicações. Editora Unesp.

Moreira, A. P. (1998). Métodos de cálculo de coordenadas tridimensionais para o controle de obras de engenharia. Tese de Doutorado. Universidade de São Paulo.

Möser, M.; Schlemmer, H.; Müller, G. (2000). Sensoren und Verfahren der Ingenieurvermessung.

Nadal, C. A. (2000). Método da interseção óptica tridimensional aplicado à engenharia de precisão. 116f. Tese de Doutorado. Tese (Doutorado em Ciências Geodésicas)-Setor de Ciências da Terra, Universidade Federal do Paraná, Curitiba.

Nero, M. A., Cintra, J. P., Ferreira, G. D. F., Pereira, T. Á. J., \& Faria, T. S. (2017). A computational tool to evaluate the sample size in map positional accuracy. Boletim de Ciências Geodésicas, 23(3), 445-460.

Okiemute, E. S., Ono, M. N., \& Oduyebo, O. F. (2018). Comparative Analysis of DGPS and Total Station Accuracies for Static Deformation Monitoring of Engineering Structures. IOSR Journal of Environmental Science, Toxicology and Food Technology (IOSR-JESTFT), 12(6), 19-29. 
Palazzo, D., Friedmann, R., Nadal, C., Santos, F. M., Veiga, L., \& Faggion, P. (2006). Dynamic monitoring of structures using a robotic total station. In Proceedings of the Shaping the Change XXIII FIG Congress, Munich, Germany (Vol. 813).

Silva, G. P.; De Seixas, A.; Garnés, S. J. A.; Romão, V. M. C. (2015). Definição do Sistema de Referência para a locação de Edificações Prediais - Área Experimental: Bairro da Madalena, Recife - PE. Revista Brasileira de Cartografia, v. 67, n. 2, 24 jun.

Silva, Irineu; Segantine, Paulo. (2015). Topografia para engenharia: teoria e prática de geomática. Elsevier Brasil.

Silva, D. C.; Botelho, F. J. L.; Carvalho, P.R.C. (2003). Ajustamento de poligonais levantadas com GPS. In: XXI Congresso Brasileiro de Cartografia.

Simões, D. P.; Albarici, F. L.; Borges, P. A. F. (2017). Análise comparativa das coordenadas no Sistema Geodésico Local e no Sistema Topográfico Local. R. bras. Geom., Curitiba, v. 5, n. 1, p. 062081.

Souza, W. D. O. (2012). Aplicação de Métodos para Determinação do Desvio da Vertical na Integração de Posicionamento GNSS com Levantamentos Topográficos. Dissertação de Mestrado. Programa de Pós-graduação em Ciências Geodésicas e Tecnologias da Geoinformação. UFPE.

Staiger, R., (1988). Theoretische Untersuchungen zum Einsatz von Industriemeßsystemen. Dissertation, DGK, Reihe C, Heft Nr. 340.

Roic, Miodrag. (1996). Erfassung von nicht signalisierten 3D-Strukturen mit Videotheodoliten. Inst. für Photogrammetrie und Fernerkundung.

Torge, W. (1991). Geodesy, W. de Gruyter. Berlin-New York. 